DOI: https://doi.org/10.15407/techned2018.06 $: \underline{062}$

\title{
AN INFLUENCE OF THE FACTS UPON AN ELECTRICAL NETWORK'S MODE DURING DIRECT START-UP OF AN ASYNCHRONOUS MACHINE IN THE COMPLEX LOAD'S COMPOSITION
}

Journal

Publisher

ISSN

Issue

Pages
Tekhnichna elektrodynamika Institute of Electrodynamics National Academy of Science of Ukraine 1607-7970 (print), 2218-1903 (online)

No 6, 2018 (November/December)

$62-68$

\section{Authors}

O.F. Butkevych*, O.I. Chyzhenko, O.M. Popovych ${ }^{\star *}$, I.V. Trach ${ }^{\star \star *}$ Institute of Electrodynamics National Academy of Sciences of Ukraine, pr. Peremohy, 56, Kyiv, 03057, Ukraine, e-mail: butkevych@ied.org.ua, alivchizh@ukr.net, popovich1955@ukr.net, igor.trach@ied.org.ua

* ORCID ID : http://orcid.org/0000-0002-6613-0911

** ORCID ID : http://orcid.org/0000-0002-9238-5782

*** ORCID ID : http://orcid.org/0000-0002-3345-2324

\section{Abstract}

An influence of the proposed Flexible Alternating Current Transmission System (FACTS) on the processes of direct start-up of a powerful asynchronous machine (AM) included in the complex load's node of the electrical network (EN) has been studied. The construction and study of the EN model containing AM and FACTS were performed in the MATLAB-Simulink environment. 
Obtained results indicate that FACTS significantly limits an influence of the AM start-up current on the parameters of the EN's mode. References 10, figures 5, table 1.

Key words: electrical network, direct start-up of an asynchronous machine, FACTS.

Received: 28.02 .2018

Accepted: 31.08 .2018

Published: 23.10 .2018

\section{References}

1. Butkevych O.F., Kostyrya I.A. Using FACTS to increase a throughput of electrical networks. Pratsi Instytutu elektrodynamiky Natsionalnoi Akademii Nauk Ukrainy . 2016. No 44. Pp. 5-12. (Ukr)

2. Handbook on the repair of large electric motors. Moskva: Energoatomizdat, 1985. 272 p. (Rus)

3. Chyzhenko O.I., Trach I.V. An adjustment of a weak electrical network's mode when starting an electric motor of comparable power. Pratsi Instytutu elektrodynamiky Natsionalnoi Akademii Nauk Ukrainy . 2017. No 48. Pp. 27-32. (Ukr)

4. Dubey R.K., Suman S.K. Control of Power System Stability through FACTS. International Journal of Scientific Engineering and Applied Science (IJSEAS). 2015. Vol. 1. No 8. Pp. 352-359.

5. Hingorari N.G., Gyugyi L. Understanding FACTS. Concepts and Technology of Flexible AC Transmission Systems. New York: IEEE Press, 2000. 432 p.

6. Padiyar K.R. FACTS Controllers in Power Transmission and Distribution. Published by New Age International (P) Ltd., Publishers, 2007. 532 p.

7. Popovych O.M., Golovan I.V. Study of changed main flux reactance of squirrel-cage induction motors using field analysis of their starting characteristics. Tekhnichna 
No 5. Pp. 69-72.

8. Selecting the right strategy for starting large motors. Application edge. 2016. Vol. 1. No 3. URL:

https://www.tmeic.com/sites/default/files/assets/files/library/Application\%20Edge-v1i3-Starting \%20Large\%20Motors.pdf

9. Softstarter Handbook. URL: https://library.e.abb.com/public/6b4e1a3530814df0c12579b b0030e58b/1SFC132060M0201.pdf

10. When to use a Soft Starter or an AC Variable Frequency Drive. Rockwell Automation

Publication 150-WP007A-EN-P. October 2014. 22 p. URL: http://literature.rockwellautomation .com/idc/groups/literature/documents/wp/150-wp007 -en-p.pdf

$\underline{\text { PDF }}$ 